Abbreviated Key Title: Sch J Agric Vet Sci

ISSN 2348-8883 (Print) | ISSN 2348-1854 (Online)

Journal homepage: https://saspublishers.com/sjavs/

\title{
Proboscis Monkey's Hematology Profile in South Kalimantan
}

Irma Padeta $^{1 *}$, Teguh Budipitojo ${ }^{1}$, Rini Widayanti ${ }^{2}$, Slamet Raharjo ${ }^{3}$, Heri Budi Santoso ${ }^{4}$, Amalia Rezeki ${ }^{5}$

\footnotetext{
${ }^{1}$ Department of Anatomy, Faculty of Veterinary Medicine, Universitas Gadjah Mada, Yogyakarta, Indonesia

${ }^{2}$ Department of Biochemistry and Biology Molecular, Faculty of Veterinary Medicine, Universitas Gadjah Mada, Indonesia

${ }^{3}$ Department of Internal Medicine, Faculty of Veterinary Medicine, Universitas Gadjah Mada, Yogyakarta, Indonesia

${ }^{4}$ Department of Biology, Faculty of Mathematics and Natural Sciences, Universitas Lambung Mangkurat, South Kalimantan, Indonesia

${ }^{5}$ Sahabat Bekantan Indonesia Foundation, South Kalimantan, Indonesia
}

DOI: $10.36347 /$ sjavs.2020.v07i03.001

| Received: 06.03.2020 | Accepted: 13.03.2020 | Published: 19.03.2020

*Corresponding author: Irma Padeta

\section{Abstract}

\section{Original Research Article}

Proboscis monkey (Nasalis larvatus) is one of the endemic species in Kalimantan. Nowadays, they are belonging to endangered species based on IUCN assessment. Blood examination is important for body health evaluation, especially in non-human primates where lived in a zoo, animal captive or rehabilitation center. The study was carried out to examine the hematology profile of female-juvenile proboscis monkey blood cells in Sahabat Bekantan Indonesia in Banjarmasin, South Kalimantan. Blood samples were collected from four female-juvenile probosci's monkey at Sahabat Bekantan Indonesia. The sample was examined for hematology and blood morphology profile. The hematology profile showed the mean of erythrocytes, the erythrocytes indices, the mean of leukocytes, the differential of leukocytes and the mean of platelets. The morphology of proboscis monkey blood cells was similar to other domestic animals, even though the shape and size were various. In conclusion, there was no blood cell abnormality and the hematology profile could be a clinical parameter for monitoring and evaluating female-juvenile proboscis monkey in the rehabilitation center.

Keywords: Blood cells, morphology, Proboscis monkey, profile, South Kalimantan.

Copyright @ 2020: This is an open-access article distributed under the terms of the Creative Commons Attribution license which permits unrestricted use, distribution, and reproduction in any medium for non-commercial use (NonCommercial, or CC-BY-NC) provided the original author and source are credited.

\section{INTRODUCTION}

Indonesia is the second of the highest biodiversity country in the world [1] and twenty percent of primate species is found in Indonesia [2]. Proboscis monkey (Nasalis larvatus) is one of the endemic species in Kalimantan [3, 4]. This primate belongs to Colobinae subfamily and distributed in Kalimantan, Sabah, Sarawak, and Brunei. According to the International Union for the Conservation of Nature and Natural Resources (IUCN) assessment, proboscis monkey belongs to endangered species [5]. The decrease of the primate population is mainly caused by deforestation and illegal trading $[3,6]$. Deforestation also allows the hunter to provide primates illegal trading [6]. The decrease of population is also expected as the main cause of the change of distribution pattern of the primate population in a certain area [7].

In Indonesia, regulation of wildlife protection, particularly for endangered species had been declared since 1931. To date, the Indonesian Ministry of Environment and Forestry declared that proboscis monkey is one of the twenty-five species which has been increased in population. Increasing the population by establishment and arrangement of conservation area are not only for maintaining the ecological and evolutionary process that determine the biodiversity but also for preserving the high value of biodiversity, ecologically and economically [3]. The conservation area has been important in wildlife and environment so that it is needed the ecology indicator as an environment quality determinant. Several forest areas used protected primates as an indicator whose lives depend on forest and trees. Research support in proboscis monkey's conservation program is needed. Recently, the study about proboscis monkey is limited to habitat, distribution, and behavior and ecology aspect. Furthermore, proboscis monkey is a wildlife species that is intolerant in habitat destruction [8, 9]. Besides, the feed source is the ecology factor which determines primate population sustainability [10]. Feed source affects the distribution of population and energy for individual health and reproduction. In several conservation areas, zoo, captivity and rehabilitation centers, individual health is an important factor to maintain the population. Medical information is also important as a basis of science for conservation implementation, especially for medical treatment consideration. 
Blood is a connective tissue in the body, the special connective tissue which consists of 2 components, cells and plasma [11]. Blood has an important role in the body such as transportation, regulation, and protection. Blood carrying oxygen, nutrient, hormone and metabolism product to the whole body, maintaining the body temperature, $\mathrm{pH}$ and volume of body fluid. Blood also protecting the body from infection and blood loss [12]. Blood examination is important for body health screening [13, 14], especially for non-human primates where lived in a zoo, animal captive or rehabilitation center [14]. Health screening is an important part of maintaining primate welfare in captive breeding or laboratory as experimental research. Popular non-human primates that are used in biomedical research are Maqaqa mulatta (rhesus monkeys), generate scientific development which giving benefit to both, human and veterinary medicine $[15,16]$. Primate health screening is important to detection of infectious, non-infectious, behavior and nutritious disorder in animal captive [17]. Unfortunately, there is no medical data about proboscis monkey, especially for a blood profile. The study was carried out to examine the hematology profile of female-juvenile proboscis monkey blood cells in Sahabat Bekantan Indonesia in Banjarmasin, South Kalimantan.

\section{MATERIALS AND METHODS Animals and Ethic Approval}

Samples were collected from four femalejuvenile proboscis monkey (3-5 years old) from Sahabat Bekantan Indonesia, South Kalimantan. Samples were processed for blood film preparation and hematology profile examination. The method of medical examination was approved by the Ethical Clearance Committee in the Faculty of Veterinary Medicine, Universitas Gadjah Mada. The examination was the first medical check-up which was conducted as a part of cooperation among Sahabat Bekantan Indonesia, Faculty of Veterinary Medicine, Universitas Gadjah Mada and Lambung Mangkurat University.

\section{Blood Cells Profile Examination}

The blood film preparation was fixated by using methanol (Emsure, Germany) and then visualized by using Giemsa staining method. Blood film preparations were immersed in $10 \%$ Giemsa solution for 30 minutes. Blood cell morphology was observed and analyzed descriptively by using a light microscope. The photomicrograph of blood cells was taken by using Optilab ${ }^{\circledR}$ camera with $1250 \mathrm{X}$ magnification (ocular lens $12,5 \mathrm{x}$ magnification $\mathrm{X}$ objective lens $100 \mathrm{x}$ magnifications).

The blood samples were collected using a sterile needle and stored in the vacutainer containing EDTA. Furthermore, samples were examined for erythrocytes, hemoglobin $(\mathrm{Hb})$, leukocytes (neutrophils, eosinophils, basophils, monocytes, and lymphocytes), platelets, pack cell volume (PCV), mean corpuscular volume (MCV), mean corpuscular hemoglobin $(\mathrm{MCH})$ and mean corpuscular hemoglobin concentration (MCHC).

\section{RESULTS AND DISCUSSION}

Hematology information is crucial for ensuring animal health and welfare, and normal data is important to individual disorder detection [13]. Proboscis monkey is an endemic non-human primate from Kalimantan and their existence was endangered. The population of proboscis monkey is declining in habitat area. In situ habitat is a conservation effort to maintain of population. Beside, ex-situ habitat is also conservation effort realization from government, public community, non- government organization or educational institution for conserving the population. Sahabat Bekantan Indonesia foundation is a non-government organization which collaborates with an educational institution for supporting government program in proboscis monkey rehabilitation and conservation [18]. The previous study reported that minimum scientific information and malnutrition impacted to failure of proboscis monkey captivity [19].

There was no blood parasite detected on blood film preparation. Fig.1.A showed the morphology of erythrocytes. Proboscis monkey's erythrocytes were showed biconcave, round and anucleate. The morphology correlates with the erythrocyte maturation process. During maturation, they produce hemoglobin to bind oxygen. The nucleus dissolved before erythrocyte entered and the powerful phagocytes, they enter the tissue and to bind by hemoglobin in the circulation [20]. Besides, the erythrocyte center was pale, it similar to dog erythrocytes and other domestic animals $[11,21]$. The various appearance of blood cell morphology also detected on the blood smear preparation quality and location of the smear on the object-glass.

Granulocytes and agranulocytes were detected on blood smear preparation of proboscis monkey. The morphology was larger than erythrocytes but less in amount. Based on cytoplasmic granule and nucleus, neutrophils, basophils, and eosinophils include in polymorphonuclear granulocytes while monocytes and lymphocytes include in mononuclear agranulocytes [11, 22]. Polymorphonuclear leukocytes have various forms of nucleus, particularly neutrophils. Proboscis monkey's neutrophil morphology was round, the nucleus was segmented and the cytoplasm was pale (Fig.1.B). The morphology of neutrophil was the same as other domestic animals [11]. Furthermore, basophil was also detected on proboscis monkey's blood smear. Basophil morphology was round, the nucleus was segmented, and the cytoplasm was stain dark-purple (Fig.1.C). Basophils percentage is the smallest among leukocytes in the blood circulation of domestic mammals. The cells were round-oval, the nucleus was 
irregular, segmented, and bilobed. Basophils cytoplasm was reddish-purple or dark purple [11].

Proboscis monkey's eosinophils granules are pink or red (Fig.1.D). Various sizes and numbers, moreover the granules do not usually fill the cell cytoplasm. The nucleus of eosinophils has several lobes but less than neutrophils. The previous study reported eosinophils nucleus of several domestic mammals has various forms such as kidney-shaped in pigs and Cshaped on ruminants [11]. The neutrophil is predominant leukocytes in circulation, cytoplasm granules containing enzymes and chemotactic factors are specific against microorganisms whereas cytoplasm granules of eosinophil are specific for the allergic mediator. However, eosinophil also has the same role as neutrophil. Basophil has the smallest portion in circulation, but the cytoplasm granules also mediate inflammatory response [20].
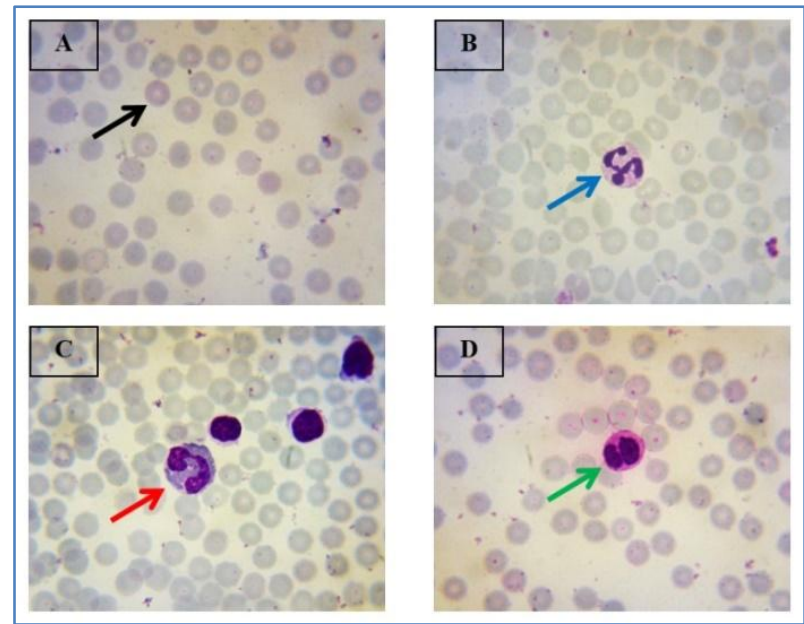

Fig-1: The morphology of erythrocytes and granulocytes (Giemsa; 1250X). Erythrocytes (black arrow) were round and anucleate, the shape was biconcave (A). Neutrophil (blue arrow) was round, the nucleus was segmented and the cytoplasm was pale (B). Basophil (red arrow) was round, segmented nucleus and the dark-purple cytoplasm was detected $(\mathrm{C})$. Eosinophil (green arrow) was round, the nucleus was segmented kidney shaped nucleus and cytoplasm was reddish-purple (D)

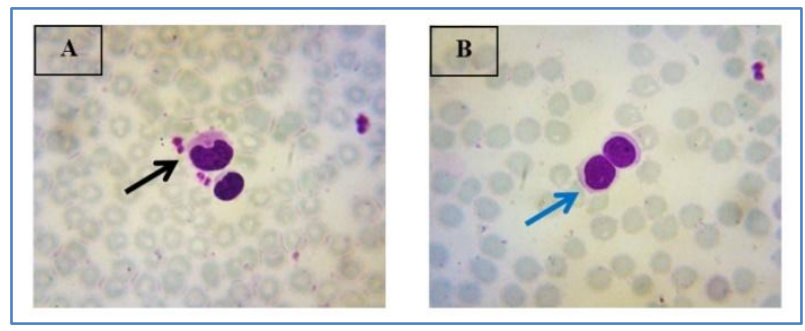

Fig-2: The morphology monocyte (A) and lymphocyte (B) (Giemsa; 1250X). Monocyte (black arrow) was round and large and the nucleus was horseshoe-shape. Lymphocyte (blue arrow) was round and large, the large nucleus was almost filling the cell

Fig.2.A and Fig.2.B showed the monocytes and lymphocyte morphology, respectively. Proboscis monkey's monocyte was round and large cells, the nucleus was observed horseshoe-shape like. Mammal monocytes nucleus was various, oval, kidney-shaped, horseshoe-shape, and irregular [11]. The shape of proboscis monkey's lymphocyte was round, the nucleus was round and large, almost filling the whole cell. Some domestic animal's lymphocytes were detected in various sizes. Large lymphocytes have smaller and paler nucleus than small lymphocytes but the cytoplasm was abundant in small lymphocytes compared to the large one [11]. Monocytes are the largest blood cell [23] and powerful phagocytes; they enter the tissue and differentiate into macrophages against microorganisms and debris phagocytosis. Lymphocytes have various size, lymphocytes are specific to antibody production after they differentiate into plasma cells and they are significant in immunology response [20].

A blood cell profile is one of the clinical parameters to monitor and evaluate primate health and to determine the effective treatment for unhealthy animals [14]. The female-juvenile proboscis monkey's hematology examination result was showed in Table 1 . No differences in blood profile analysis component among species. The component of blood profile analysis is the erythroid examination, differential of leukocytes, platelet measurement, and morphology assessment [24]. Hemoglobin, PVC, MCV, MCH, and MCHC are essential to diagnose a disease, especially red blood cell disorder. These parameters correlated to erythrocyte morphology. Hemoglobin and PCV are examined for anemia detection. Mean corpuscular volume represents the total volume of erythrocytes in the sample. On the blood film preparation, MCV value also gives information about cell size (normocytic, microcytic and macrocytic). Mean corpuscular hemoglobin is the parameter to detect hemoglobin value in erythrocyte whereas MCHC is providing the hemoglobin contain in erythrocyte and it describes as normochromic and hyperchromic [25]. The other blood cell is platelets that have coagulation function. Platelets are localized at the injury site after vasoconstriction to prevent blood loss. Mammalian platelets are small and anucleate [22] but they have granules in central cells [11]. On the blood smear preparation, platelets detected as single or cluster cells. 
Table-1: Hematology profile of proboscis monkey

\begin{tabular}{|l|l|}
\hline Hematology parameter & Mean \pm SD \\
\hline Hemoglobin $(\mathrm{g} / \mathrm{dL})$ & $11.6 \pm 0.48$ \\
\hline Leukocytes $\left(10^{3} / \mu \mathrm{L}\right)$ & $14.0 \pm 3.12$ \\
\hline Erythrocytes $\left(10^{6} / \mu \mathrm{L}\right)$ & $4,50 \pm 0.07$ \\
\hline Platelets $\left(10^{3} / \mu \mathrm{L}\right)$ & $345.8 \pm$ \\
& 153.64 \\
\hline Packed cell volume $(\%)$ & $35.9 \pm 2.55$ \\
\hline Basophils $(\%)$ & $1.3 \pm 1.13$ \\
\hline Eosinophils $(\%)$ & $0,0 \pm 0.05$ \\
\hline Neutrophils $(\%)$ & $36,7 \pm 6.90$ \\
\hline Lymphocytes $(\%)$ & $58,9 \pm 6.03$ \\
\hline Monocytes $(\%)$ & $3,8 \pm 0.95$ \\
\hline Mean corpuscular volume $(\mathrm{fl})$ & $79.7 \pm 5.22$ \\
\hline Mean corpuscular hemoglobin $(\mathrm{pg})$ & $25,7 \pm 0.90$ \\
\hline Mean corpuscular hemoglobin concentration $(\%)$ & $32,2 \pm 1.04$ \\
\hline
\end{tabular}

Hematology profile was important biomedical information for the animals. It is used as a scientific direction to diagnose the disease and manage the treatment [26]. Hematology profile is necessary to evaluate health status in captive breeding or rehabilitation center for conservation purposes. The blood profile of Macaques (Macaca mulatta) in the captive animal has been reported for clinical health [14]. Besides, Macaca fascicularis's blood profile in their habitat was assessed for investigated physiological parameters for research utilization [27]. Sex, age, body weight, breed, and habitat are influenced factors for the hematology parameter value [28]. Hematology count of Rhesus Macaca mulatta which had been reported in South-West China showed that erythrocytes and hemoglobin are significantly higher on males compared to females. On the contrary, neutrophils and eosinophils are significantly higher on the female. Then, ages also affected on the lymphocytes and platelets, those indicated that the older of individual, the higher the value of cells [29]. The age of proboscis monkey used in this study was 3-5 years old. This condition was similar to the previous study about Rhesus monkey hematology. Then, it was suggested that more samples are needed to give significant results related to age factor [29]. Habitat also affected to non-human primate hematology profile. Comparison between Cynomolgus monkeys in Southeast Asia and Asian macaques in Mauritius showed differences in MHC [28]. Proboscis monkey is an endemic primate, only founded in Kalimantan Island. Blood samples were collected from the rehabilitation center so it was suggested that there were differences possibility on the result compared to proboscis monkey from nature, also compared to several regions in Kalimantan Island. However, the previous study reported that the hematology profile among non-human primates (Baboon, Cynomolgus and Rhesus monkey) is similar significantly [29-31].

Slight differences among species of nonhuman primates also detected. Neutrophils and lymphocytes value of Rhesus monkey and Cynomolgus monkey were higher than Baboon. On the other hand, anesthesia conditions affected to hematology count, particularly on neutrophils count [29]. Proboscis monkey blood collection was not under anesthesia condition. It was suggested that proboscis monkey under stress condition. The condition should be possible for oversight results [29]. Blood cell morphology which is detected on the smear preparation also affected by several factors. The factors are sample condition, smear preparation quality, and anticoagulant utilization [11] Then, mostly non-human primate's study has a small sample size. Therefore, further study about the hematology profile should be implemented to compare the data based on the influenced factor.

\section{CONCLUSION}

The hematology profile could be considered as a clinical parameter in the laboratory for monitoring and evaluating female-juvenile proboscis monkey in the rehabilitation center and the morphology of proboscis monkey's blood cells were similar to other domestic animals, even though the shape and size were various.

\section{ACKNOWLEDGMENTS}

Authors would like to thank the Directorate of Research, Universitas Gadjah Mada for fully funding this study, Sahabat Bekantan Indonesia (SBI) Foundation, Department of Biology, Faculty of Mathematics and Natural Sciences, Universitas Lambung Mangkurat, and also Natural Resources Conservation Center (BKSDA) Banjarmasin for implementation of cooperation and collaboration. The authors would also like to thank the Department of Anatomy that supported and facilitated this study.

\section{REFERENCES}

1. Wahyono S, Shalahuddin L. Direktori Penelitian Asing di Indonesia. Sekretariat Perijinan Penelitian Asin. Biro Hukum dan Humas, Kementerian Riset dan Teknologi. 2011; 20881916. 
2. Supriatna J, dan EH. Wahyono. Panduan Lapangan Primata Indonesia. Yayasan Obor Indonesia. Jakarta;2000.

3. Bismark M. Proboscis Monkey (Nasalis larvatus): Bioecology and Conservation. in Indonesian Primates. S Gursky-Doyen, J Supriatna (EDS). Springer. New York;2010.

4. Groves CP. Primate Taxonomy. Smithsonian Institution Press. Washington DC, USA;2001.

5. Meijaard E, Nijman V and Supriatna J. Nasalis larvatus. The IUCN Red List of Threatened Species; 2008: e.T14352A4434312.

6. Pastor-Nieto R. Health and welfare of Howler Monkeys in captivity. Spinger Science+Business Media: New York; 2015.

7. Cuaron AD. Conservación de los primates y sus habitats en el sur de México. MSc thesis. Universidad Nacional, Costa Rica; 1991.

8. Wilson CC and Wilson WL. The influence of selective logging on primates and some other animals in East Kalimantan. Folia Primatologica. 1975;23: 245-274.

9. Yeager CP. Changes in proboscis monkey (Nasalis larvatus) group size and density at Tanjung Puting National Park, Kalimantan Tengah, Indonesia. Tropical Biodiversity I.1992; 1: 49-55.

10. Meijaard E and Sheild D. Hutan pasca pemanenan melidungi satwa liar dalam kegiatan hutan produksi di Kalimantan. CIFOR, Bogor; 2006.

11. Bacha Jr, WJ, dan Bacha LM. Color Atlas of Veterinary Histology. Lippincott Williams \& Wilkins. Pennsylvania: USA; 2012.

12. Cunningham J. Textbook of Veterinary Physiology. Saunders. Santolouis, Missouri, USA; 2007.

13. Aliko V. Comparative blood cell morphology in the peripheral blood films from different vertebrate classes with an adaptation and evolutionary approach; Proceeding of International Conference on Biological and Environmental Sciences. September; 2008.

14. Rajan MP, Jayathangaraj MG, Sridhar R, Parthiban M. Haematology of captive rhesus macaques (Macaca mulatta). Tamilnadu Journal of Veterinary and Animal Sciences. 2013, 9 (2): 137140.

15. Moberg G. P. 1999. When does stress become distressed. Laboratory Animals. 2012;28: 22-6.

16. Smith JJ, Hadzic V, Li C, Liu P, Day T, Utter A, Kim B, Washington IM, Basso AA. Objective measure of health and well-being in laboratory rhesus-monkeys (Macaca mulata). Journal of Medical Primatology. 2006; 35: 388-396.

17. Suedmeyer WK. Preventative health care for primates in captivity. The USDA Primate Symposium 2017. www.primatecare.com.
18. Sinaga E, Setia TM, Saribanon N, Makur KP, Wicaksono G, Wigatiningrum T, Koritelu MC. Konservasi Bekantan Berbasis Masyarakat di Pulai Bunyu. Sekolah Pascasarjana Universitas Nasional: Jakarta; 2015.

19. Agoramoorthy G, Alagappasamy C, Hsu MJ. Can proboscis monkeys be successfully maintained in captivity? a case of swings and roundabouts. Technical report. Zoo Biology.2004; 23: 533-544.

20. Eroschenko, Victor P. diFiore's Atlas of Histology with Functional Correlation. Lippincot Williams \& Wilkins: USA; 2008.

21. Berger Anne M. Erythrocyte Morphology. In: Weiss D. J. and Wardrop, K. J. Schalm's Veterinary Hematology. Wiley Blackwell: USA.2010.

22. Loffler H, Rastetter J, Haferlach T. Atlas of Clinical Hematology. Springer, USA; 2005.

23. Banks, William J. Applied Veterinary Histology. Mosby: Missouri; 1993.

24. Canfield PJ. Comparative cell morphology in the peripheral blood film from exotic and native animal. Australian Veterinary Journal.1998; 76(12): 793-800.

25. Tvedten H. Laboratory and Cliical Diagnosis of Anemia. In: Weiss D. J. and Wardrop, K. J. Schalm's Veterinary Hematology. Wiley Blackwell: USA.2010.

26. Bonfanti U, Lamparelli D, Colombo P, Bernardi C. Hematology and serum chemistry parameters in juvenile cynomolgus monkeys (Macaca fascicularis) of Mauritius origin: comparison between purpose-bred and captured animals. Journal of Medical Primatology. 2009; 38. 228235.

27. Soma IG, Wandia IN, Putra, IG AA, Silta R. Profil darah moyet ekor panjang (Macaca fascicularis) liar di habitat alami. Jurnal Ilmu dan Kesehatan Hewan. 2013; 1(1): 22-28.

28. Xie L, Xu F, Liu S, Ji Y, Zhou Q, Wu Q, Gong W, Cheng K, Li J, Li L, Fang L, Zhou L, Xie P. Age and sex-based hematological and biochemical parameters for Macaca fascicularis. PloS one.2013; 8(6).

29. Chen Y, Qin S, Ding Y, Wei L, Zhang J, Li H, Bu $\mathrm{H}$, Lu Y, Cheng J. Reference values of clinical chemistry and hematology parameters in rhesus monkeys (Macaca mulatta). Xenotransplantation. 2009; 16: 496-501.

30. Schuurman HJ, Smith H, Cozzi E. Reference values for clinical chemistry and clinical hematology parameters in baboons. Xenotransplantation. 2004;11: 511-516.

31. Schuurman HJ and Smith HT. Reference values for clinical chemistry and clinical hematology parameters in cynomolgus monkeys. Xenotranplantation. 2005;12: 72-75. 